\title{
Estimation of Spatial Groundwater Recharge Using WetSpass Model for East Wasit Province, Iraq
}

\author{
Hassan Jameel Al-Badry ${ }^{1, *} \mid$ Mohammed S. Shamkhi ${ }^{1}$
}

\section{Affiliations \\ 1Department of Civil Engineering, University of Wasit, Wait, Iraq \\ Correspondence \\ Hassan Jameel Al-Badry, Department of Civil \\ Engineering, University of \\ Wait, Wasit, Iraq \\ Email: hjalbadry@gmail.com \\ Received \\ 13-October-2021 \\ Revised \\ 14-November-2021 \\ Re-revised \\ 3-December-2021 \\ Accepted \\ 12- December-2021 \\ Doi: 10.31185/ejuow.Vol9.Iss2.273}

Keywords: Groundwater recharge, WetSpass model, east Wasit province, spatial distribution

\begin{abstract}
Groundwater is an important water source, especially in arid and semi-arid areas. Recharge is critical to managing and analyzing groundwater resources despite estimation difficulty due to temporal and spatial change. The study aim is to estimate annual groundwater recharge for the eastern Wasit Province part, Iraq. Where suffers from a surface water shortage due to the region's high elevation above Tigris River water elevation by about $60 \mathrm{~m}$, it is necessary to search for alternative water sources, such as groundwater use. The spatially distributed WetSpass model was used to estimate the annual recharge. The inputs for the model were prepared using the ARC-GIS program, which includes the topography and slope grid, soil texture grid, land use, groundwater level grid, and meteorological data grids for the study area for the period (2014-2019). The result shows that the annual recharge calculated using the WetSpass model (2014-2019) varied of 0 to $65.176 \mathrm{~mm} /$ year at an average of $27.117 \mathrm{~mm} /$ year, about $10.8 \%$, while the rate of the surface runoff was $5.2 \%$ and Evapotranspiration formed $83.33 \%$ of the annual rainfall rate of $251.192 \mathrm{~mm}$. The simulation results reveal that the WetSpass model simulates the components of the hydrological water budget correctly. For managing and planning available water resources, a best grasp of the simulation of long-range average geographical distribution around the
\end{abstract}

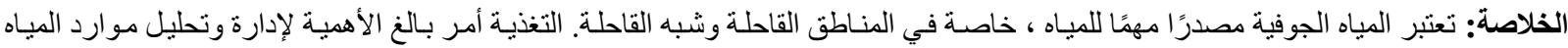

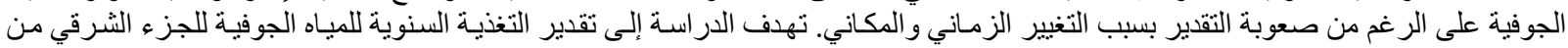

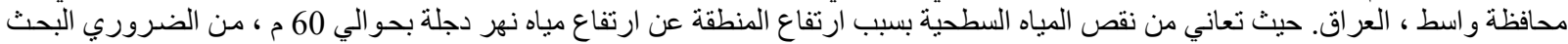

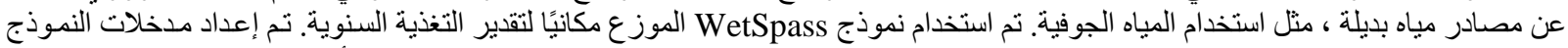

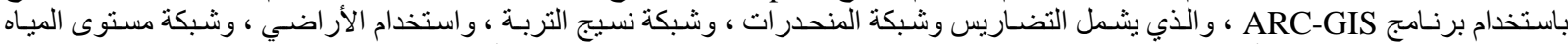

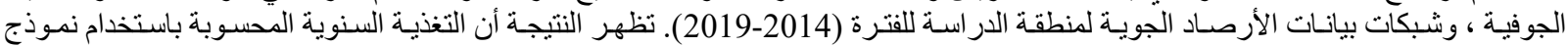

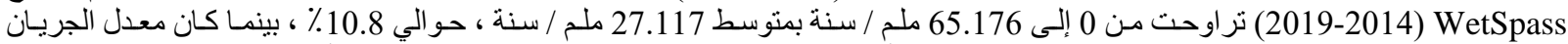
السطحي 5.2٪ وشكل التبخر النتح 2014.33 83 ٪ من معدل هطول الأمطار السنوي

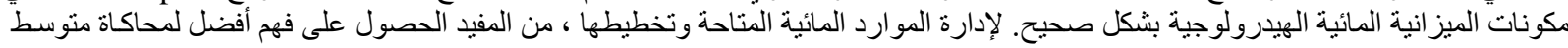

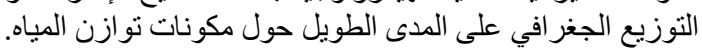

\section{INTRODUCTION}

The world's largest freshwater resource is groundwater, which is essential for irrigated agriculture and, as a result, for global food security. Despite this, large groundwater systems have been depleted in both semi-arid and humid regions of the globe. The primary source of depletion is excessive irrigation extraction in areas where groundwater is slowly recharged, and climate change can exacerbate the situation in particular areas. Therefore, groundwater levels must be stabilised in such areas for long-term food production to be sustainable. To do this, we must change the way we value, manage, and classify groundwater resources [1]. Groundwater is the subsurface water that exists under the water table in soils and geologic formations completely saturated [2]. One of the most significant natural resources on the planet is groundwater. Many major cities and small towns worldwide rely on groundwater for their water supplies, owing to its quantity, consistent quality, and low cost of extraction [3]. 
To determine the amount of recharge from rainfall, it is necessary to understand the relationships between rainwater and surface runoff. The first step is determining the portion of precipitation available to recharge groundwater after subtracting the lost land flow (surface runoff) and evapotranspiration ET. Groundwater recharge is an important parameter that controls groundwater's state and fluctuations and needs a complete evaluation. The groundwater recharge is affected temporally and spatially by many factors such as meteorology, soil characteristics, geology, surface cover, slope, and depth of the groundwater table [4].

WetSpass is an acronym for transferring water and energy between soil, plants, and the atmosphere in a quasistatic state. WetSpass is a spatial distributed hydrological model. This model was created at the Vrije Universiteit Brussels Department of Hydrology and Hydraulic Engineering and is thoroughly explained in various publications [5]. It is a physical model used to estimate long-term mean spatial patterns of runoff, actual evapotranspiration, and groundwater recharge employing physical and empirical relationships. It is a model embedded within GIS (ARC View), coded in Avenue, built into ARC View. Several studies have used the WetSpass model in different regions of the world and different circumstances. It gave good results and recommended using the WetSpass model in calculating the water balance components as it provides accurate results $[6,5,7.8,9,10,11,12,13,14,15,16,17,18,19,20$, and 21]. It is constructed using WetSpa, a time-dependent spatially distributed water balance model. Grids of land use, groundwater level, precipitation, potential evapotranspiration, wind-speed, temperature, soil, slope, and topography are used inputs in this model, with factors like soil texture, land use and runoff linked to the model in the form of attribute tables [5].

Seasonal and annual runoff and evapotranspiration are deducted from seasonal and annual precipitation, the WetSpass model calculates the quantity of the long-range seasonal and annual geographical distribution of groundwater recharge [12]. The model allows researchers to understand better and estimate interactions between the atmosphere and surface water and groundwater and produces a spatially distributed recharge needed for further groundwater modelling and simulation. It also estimates other seasonal hydrological components that are spatially distributed, such as evapotranspiration, transpiration, surface runoff, interception, and evaporation from the soil [7]. Many studies were conducted on the study area, where the surface runoff was calculated [22], and the SWAT model was used to calculate the surface runoff $[23,24]$. The morphometric analysis was conducted for the study area [25], but the groundwater recharge was not calculated for the study area in the previous studies. The study aims to estimate the recharge of groundwater distributed spatially in the eastern part of Wasit Governorate, Iraq.

\section{METHODOLOGY}

\subsection{Study area}

The location of the study area is in the eastern part of Wasit Governorate, Iraq. The area covers an area of roughly $5043 \mathrm{~km}^{2}$ and includes the areas of Badra District (Jassan Zorbatiyah) and Sheikh Saad District, where the site is located between $\left(32^{\circ} 30^{\prime}-33^{\circ} 30^{\prime} \mathrm{N}\right)$ north latitude and $\left(45^{\circ} 30^{\prime}-46^{\circ} 45^{\prime} \mathrm{E}\right)$ east longitude. Figure 1 shows the study area location.

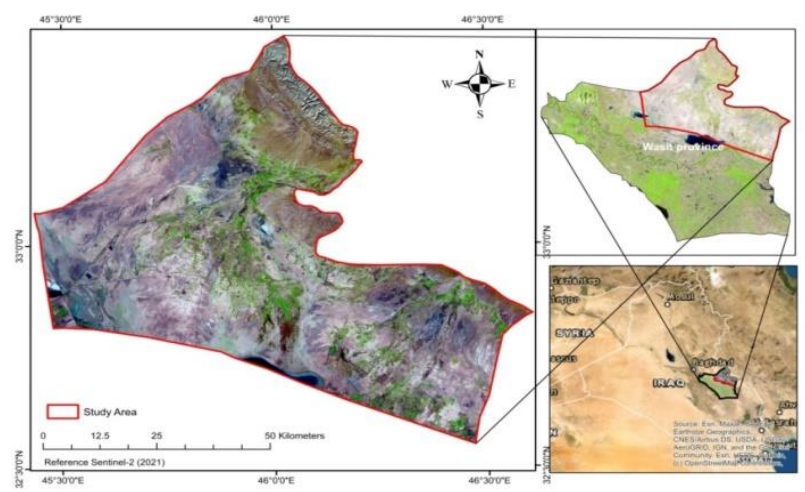

Figure 1 The Study Area Location 


\subsection{WetSpass model}

Hydrological models are frequently employed as a standard tool for investigating hydrological courses, using various applications, from tiny watersheds to global models [19]. Each model has its own set of applications, traits, and flaws. The water balance of a grid cell is calculated using the WetSpass (Water and Energy Transfer between Soil, Plants, and Atmosphere under Steady-State Conditions) model in this work (considering the fractions of bare soil, vegetation, impervious area, and open water). This model has a lot of advantages when it comes to analysing long-range average spatial styles of groundwater recharge [5]. The WetSpass model can accurately estimate groundwater recharge [26, 8, 19, and 27]. The spatial groundwater recharge yearly is estimated using the WetSpass model in this article. The following equations are used to compute the total water balance constituents of the vegetated, bare soil, open water, and impervious fraction per raster cell [6]:

$$
\begin{aligned}
& \mathrm{ET}_{\text {raster }}=\mathrm{avETv}+\mathrm{asEs}+\mathrm{aoEo}+\mathrm{aiEi} \\
& \mathrm{S}_{\text {raster }}=\mathrm{avSv}+\mathrm{asSs}+\mathrm{aoSo}+\mathrm{aiSi} \\
& \mathrm{R}_{\text {raster }}=\mathrm{avRv}+\mathrm{asRs}+\mathrm{aoRo}+\mathrm{aiRi}
\end{aligned}
$$

ET_raster, S_raster, R_raster the total evapotranspiration, surface runoff, and groundwater recharge of a raster cell have a vegetated, bare-soil, open-water, and impervious area component, denoted by av, as, ao, and ai, respectively. The water balance was discussed in each component and is as follows. The water balance for all of the components mentioned above of a raster cell is computed starting with precipitation. Then, the rest of the processes (interception, runoff, evapotranspiration, and recharge) follow logically. This order becomes a requirement for the processes to be quantified on a seasonal time scale.

\subsubsection{Vegetated Area}

The water balance in the cultivated area depends on the average seasonal rainfall (P), interception fraction (I), Surface runoff $(\mathrm{Sv})$, actual transpiration $(\mathrm{Tv})$, and groundwater recharge $(\mathrm{Rv})$, all in units of length to units time.

$$
\mathrm{P}=\mathrm{I}+\mathrm{Sv}+\mathrm{TV}+\mathrm{Rv}
$$

\subsubsection{Interception}

The interception portion is a predetermined percentage of the yearly precipitation value, depending on vegetation cover. Thus, the fraction value drops as the rain increases because the vegetation cover remains constant during the simulation period.

\subsubsection{Surface runoff}

The amount of precipitation, precipitation intensity, interception, and infiltration capacity are used to determine surface runoff, with the potential of surface runoff (Sv-pot) being calculated first:

$$
\mathrm{Sv}-\mathrm{pot}=\operatorname{Csv}(\mathrm{P}-\mathrm{I})
$$

Sv: is the surface runoff coefficient of vegetative infiltration areas being a function of vegetation cover, soil type, and slope. Surface runoff occurs in groundwater drainage areas, which leads to a very high surface runoff coefficient. The reason is the dependence on the soil, the type of vegetation cover, and the area's periphery from the river. Typically assume the coefficient is to be constant. Then, in the second step, the actual Sv - pot runoff is calculated by looking at the rainfall intensity differences concerning soil infiltration capabilities [6].

$$
\mathrm{Sv}=\mathrm{C}_{\mathrm{Hor}}-\mathrm{S}_{\mathrm{v}-\text { pot }}
$$

$\mathrm{C}_{\mathrm{Hor}}$ : It is a parameter for parameterising part of the seasonal precipitation that contributes to the Hortonian overland flow. Because all precipitation intensities contribute to surface runoff, for groundwater discharge zones $\mathrm{C}_{\mathrm{Hor}}$ equals 1.0. Surface runoff can only be generated by high-intensity storms in infiltration zones [5].

\subsubsection{Evapotranspiration}

To calculate seasonal evapotranspiration, a reference value of transpiration from open water evaporation and a vegetation coefficient are obtained [6].

$$
\mathrm{T}_{\mathrm{rv}}=\mathrm{cEo}
$$


$\mathrm{T}_{\mathrm{rv}}=$ The plant surface's reference transpiration $\left[\mathrm{LT}^{-1}\right]$

Eo $=$ Evaporation from open water $\left[\mathrm{LT}^{-1}\right]$

$\mathrm{c}=$ vegetation coefficient $[-]$

In light of the Penman-Monteith equation for the probability of open water evaporation, as shown in the Penman equation, the vegetation coefficient can be derived as a reference ratio of vegetation transpiration.

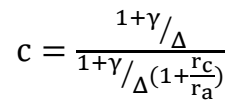

$\gamma=$ constant psychrometric $\left[\mathrm{LT}^{-1} \mathrm{~T}^{-2} \mathrm{C}^{-1}\right]$

$\Delta=$ the slope of the saturation vapour pressure curve's first derivative (the tendency for saturation vapour pressure at the predominant air temperature) $\left[\mathrm{LT}^{-1} \mathrm{~T}^{-2} \mathrm{C}^{-1}\right]$;

$\mathrm{r}_{\mathrm{c}}=$ resistance to the canopy $\left[\mathrm{LT}^{-1}\right]$ and

$\mathrm{r}_{\mathrm{a}}=$ resistance to aerodynamic $\left[\mathrm{LT}^{-1}\right]$ provided through

$$
\mathrm{r}_{\mathrm{a}}=\frac{1}{\mathrm{k}^{2} \mathrm{u}_{\mathrm{a}}}\left(\ln \left(\frac{\mathrm{z}_{\mathrm{a}-\mathrm{d}}}{\mathrm{z}_{\mathrm{o}}}\right)\right)^{2}
$$

$\mathrm{k}$ is the constant of Von Karman (0.4) [-];

$\mathrm{u}_{\mathrm{a}}$ is the wind speed $\left[\mathrm{LT}^{-1}\right]$ at the measurement level $\mathrm{z}_{\mathrm{a}}=2 \mathrm{~m}$;

$\mathrm{d}$ is the length of the zero-plane displacement $[\mathrm{L}]$ and

zo is the vegetation's or soil's roughness length [L].

The Penman coefficient $(/)$ is temperature dependent and can be found in the table below:

Table 1 Variation in Penman coefficient/values as a function of temperature

\begin{tabular}{|c|c|c|c|c|c|c|c|c|c|c|c|}
\hline $\mathbf{T}\left({ }^{\mathbf{0}} \mathbf{C}\right)$ & -20 & -10 & 0 & 5 & 10 & 15 & 20 & 25 & 30 & 35 & 40 \\
\hline $\boldsymbol{\lambda} / \boldsymbol{\Delta}$ & 5.86 & 2.83 & 1.46 & 1.07 & 0.76 & 0.59 & 0.45 & 0.35 & 0.27 & 0.25 & 0.17 \\
\hline
\end{tabular}

The values of actual transpiration Tv are equal to the values of reference transpiration. Therefore, there is no limit to the availability of soil or water for plant groundwater drainage areas.

$\mathrm{G}_{\mathrm{d}}$ is the depth of the groundwater [L];

$$
\mathrm{T}_{\mathrm{v}}=\mathrm{T}_{\mathrm{rv}} \quad \text { if }\left(\mathrm{G}_{\mathrm{d}}-\mathrm{h}_{\mathrm{t}}\right) \leq \mathrm{Rd}
$$

$\mathrm{h}_{\mathrm{t}}$ is the height of saturated tension [L], and

$\mathrm{Rd}$ is the depth of the rooting [L].

The groundwater level is lower in cultivated areas than the zone of the root, as the actual transpiration is obtained from the equation.

$$
T_{v}=f(\theta) T_{r v} \text { if }\left(G_{d}-h_{t}\right)>R d
$$

It is a function for water content, and it is defined as in a time-variant condition.

$$
f(\theta)=1-a_{1}{ }^{w} / T_{v}
$$

provided,

$$
\mathrm{w}=\left(\mathrm{p}+\theta_{F C}-\theta_{\mathrm{pwp}}\right) \mathrm{R}_{d}
$$

$a_{1}$ is a calibrated measure related to a soil type's sand content [-];

$\mathrm{w}$ is the amount of water available for transpiration $\left[\mathrm{LT}^{-1}\right]$ and

$\theta_{F C}-\theta_{\text {pwp }}$ is the plant's accessible water content. the variation in water content at field capacity per time step $\left[\mathrm{T}^{-1}\right]$ and the permanent wilting point is stated.

It is the water content available to plants $\left[\mathrm{T}^{-1}\right]$ for each time step, it is referred to as the difference in water content at the field capacity and the permanent withering point.

\subsubsection{Recharge}

Recharge is the inflow of water into a saturated groundwater area at the surface of the water level. It is estimated as a residual range for the water balance system in the model because the model determines the longrange geographically distributed average recharge as a spatial variable, which is affected by soil texture, land use, slope, and meteorological variables [28]. Recharging is when water is in motion down from surface water to a groundwater region (Vaduz) below plant roots. The WetSpass model calculates groundwater recharge as a residual term for the water balance. 


$$
\mathrm{R}_{\mathrm{v}}=\mathrm{p}-\mathrm{S}_{\mathrm{FC}}-\mathrm{ET}_{\mathrm{V}}-\mathrm{I}
$$

$\mathrm{ET}_{\mathrm{V}}$ is the real evapotranspiration [ $\mathrm{LT}^{-1}$ ] It is calculated as the total of transpiration $\mathrm{T}_{\mathrm{V}}$ and evaporation $\mathrm{E}_{\mathrm{s}}$ (evaporation from bare soil between vegetation).

After applying the above equations and relationships, spatially distributed recharge estimates can be made from vegetation type, soil type, slope, groundwater depth, precipitation, potential evapotranspiration, temperature, and wind speed. Furthermore, a little unsaturated zone is present even in discharge locations and will be some recharging associated with discharge areas. However, substantial potential transpiration due to vegetation occurs during the summer. As a result, recharge values in discharge areas are negative. A high winter recharge can occasionally compensate for low recharge numbers.

\subsubsection{The "water balance" of "bare soil, open water," and impermeable surfaces}

Recharge is estimated from the water balance of bare soil,

$$
\mathrm{P}=\mathrm{Ss}+\mathrm{Es}+\mathrm{Rs}
$$

(P) refers to precipitation, Ss is surface runoff, Es is actual evaporation, Rs is groundwater recharge measured in units of $(\mathrm{L} / \mathrm{T})$. Equation 4.4 is the same as this one, except there is no objection and the term transpiration. $\mathrm{The}_{\mathrm{ET}}$, in this case, becomes Es. The runoff is simulated in a similar way to the vegetation fraction in two stages. In the first stage, the potential surface runoff is calculated ( $\mathrm{Sv}-$ pot), and in the second stage, the actual surface runoff is calculated using equation 16 . The water balance is defined for the open water portion of a pixel is defined as:

$$
\mathrm{P}=\mathrm{So}+\mathrm{Eo}+\mathrm{Ro}
$$

$\mathrm{P}$ is precipitation, Eo is evaporation from the water surface and part of precipitation that travels across the water's surface, and $R o$ is groundwater recharge from open water, and both contain $\mathrm{L} / \mathrm{T}$ unit.

Finally, water balance is also provided for impermeable surfaces is also provided by:

$$
P=S_{i}+E_{i}+R_{i}
$$

Seasonal and annual runoff and evapotranspiration are subtracted from seasonal and annual precipitation. The WetSpass model predicts the quantities of the long-term seasonal and annual geographical distribution of groundwater recharge. Figure (2) shows a schematic representation of water balance.

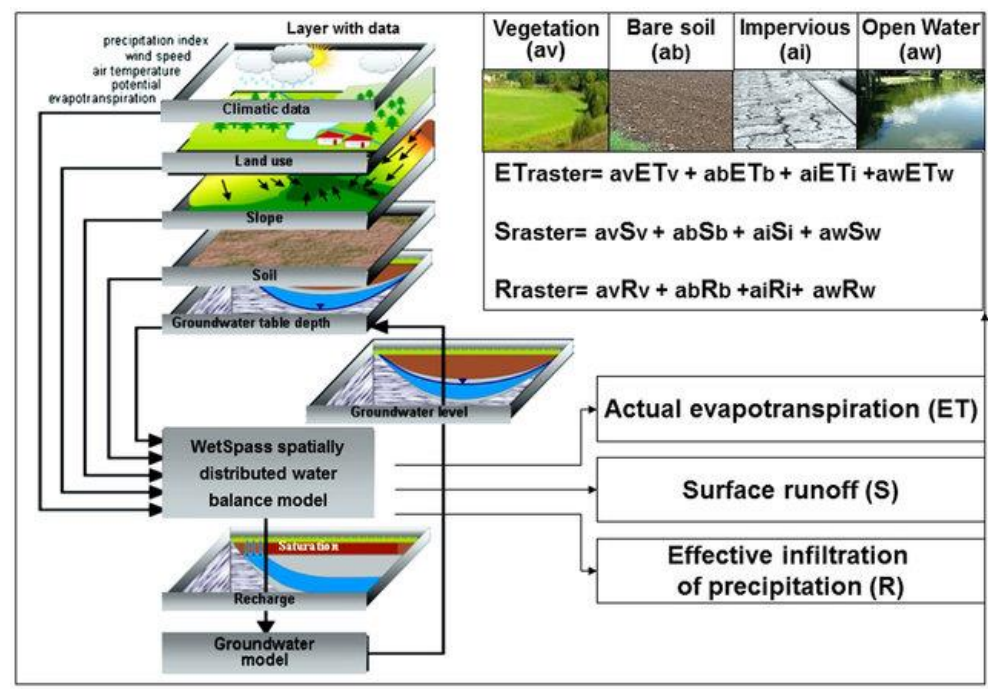

Figure 2 water balance diagram [6, 29].

\subsection{Input Data}

WetSpass model inputs maps and tables were prepared for the period (2014-2019). They are the climatic data, the land use/land cover map for 2018, the soil map for the study area, and the topography, slope data and groundwater level. In addition, the tables for the land cover parameters for winter and summer and soil and runoff were used. Thiessen polygons were chosen above other approaches because it produces more logical results [10]. 
According to the Thiessen polygon method, the climate stations shown in Table 2 was used to produce the climate maps. The input maps were prepared to the WetSpass model using GIS software, and the cell size was $30 \mathrm{~m} * 30$ m.

Table 2 The coordinates and elevations of the stations of the study area (Iraqi Meteorological organisation and seismology).

\begin{tabular}{|c|c|c|c|}
\hline Station & latitude & Longitude & Elevation(m) \\
\hline Badra & $33^{\circ} .1000$ & $45^{\circ} .9500$ & 64 \\
\hline Ali Al-Garbi & $32^{\circ} .5200$ & $46^{\circ} .8500$ & 15 \\
\hline Kut & $32^{\circ} .5000$ & $45^{\circ} .8167$ & 19 \\
\hline Aziziyah & $32^{\circ} .9167$ & $45^{\circ} .0667$ & 25 \\
\hline
\end{tabular}

\subsubsection{Topography and slope}

The US Geological Survey website (https://earthexplorer.usgs.gov/) provided the Digital Elevation Model (DEM) (SRTM) at a resolution of 30 meters for the year 2014. The topography values of the area of study range from 0 to $964.4 \mathrm{~m}$ at a rate of about $58.9 \mathrm{~m}$ above sea level with a standard deviation of 94.4. Figure (3a) shows the topography map of the study area. Slope values range from 0 to $55.46 \%$, with a mean of $2.05 \%$ and a standard deviation of 2.86. Figure (3b) shows the slope map of the study area. The basis of the WetSpass spatially distributed hydrological model is the area's topography in question since topography determines most of the hydrological processes.

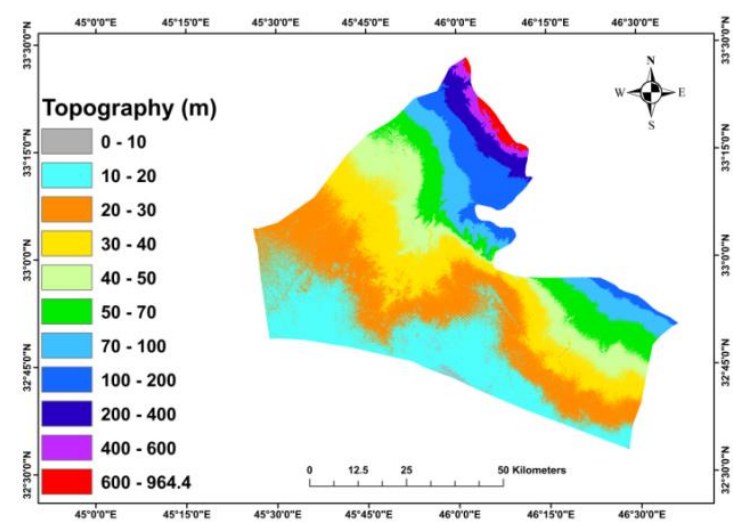

(a)

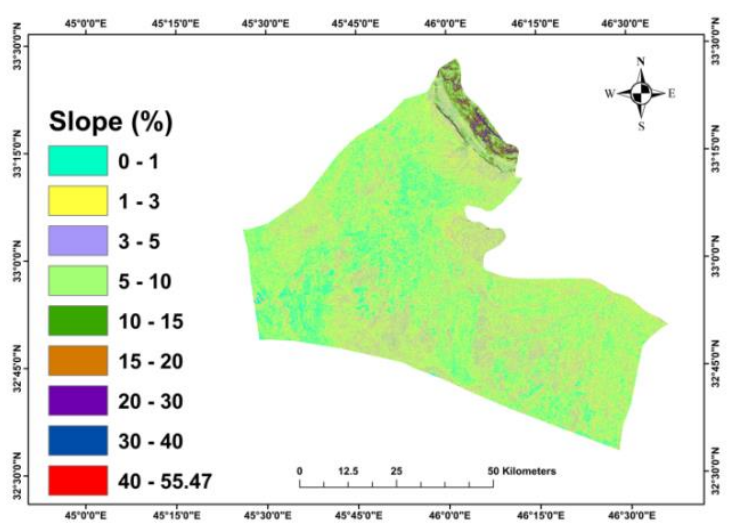

(b)

Figure 3 (a) Topography map, (b) slope map

\subsubsection{Soil texture and Land use}

The soil texture map used as an input to the WetSpass model was produced by collecting 25 soil samples from the study site, conducting the sieve analysis, examining the hydrometer and making the soil texture map shown in Figure (4a). There are seven uses recognised by the World Food and Agriculture Organization for 2018: Shrubland, Grassland, Cropland rainfed, Cropland fallow, Built-up, Bare land/sparse vegetation, and water. Bare land/sparse vegetation constitutes a large part of the study area. Figure (4b) shows land use for the study area. Permeability and soil texture are essential in calculating recharge because coarse-grained soils generally have higher recharge rates than fine-grained soils [31, 32]. Land use is essential for boundary conditions, directly or indirectly affects hydrological processes. The most apparent effect of land use on the water balance is the evapotranspiration process. Different land-use types have different evapotranspiration rates due to the difference in vegetation cover, leaf area, and root depth [6]. 


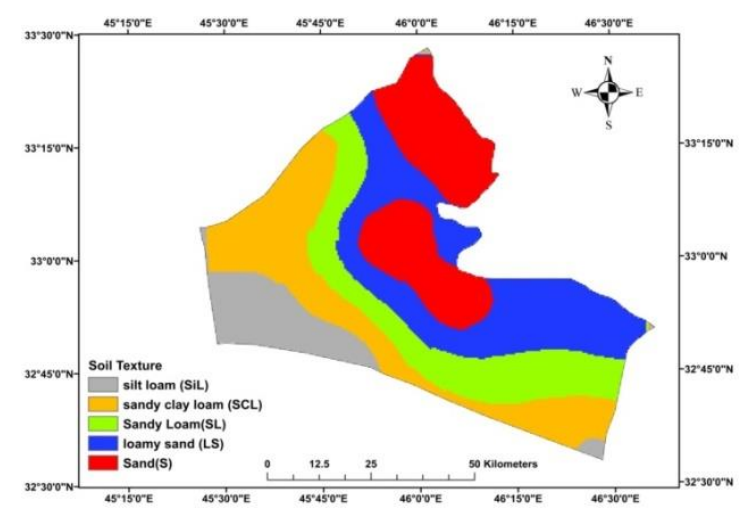

(a)

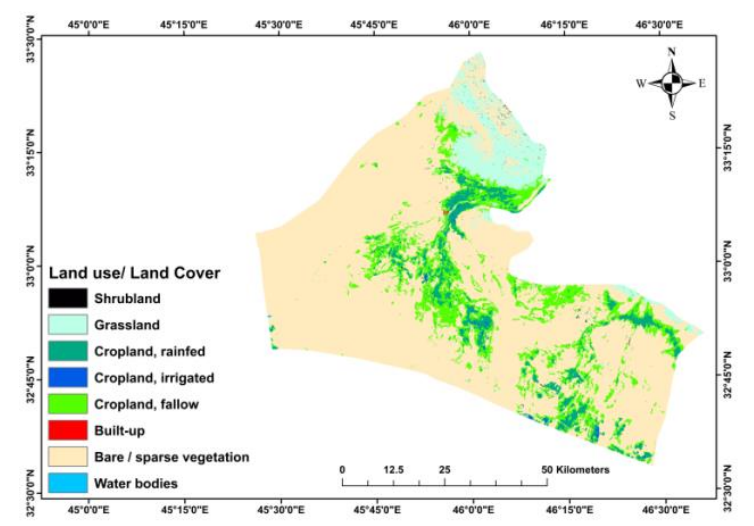

(b)

Figure 4 (a) Soil Texture for the study, (b) Land use (https://wapor.apps.fao.org/, 2018)

\subsubsection{Groundwater level}

The location of the groundwater table must be considered when estimating recharge since evapotranspiration from shallow groundwater can be considerable, especially in groundwater-dependent wetlands [5]. The groundwater table map is one of the inputs that the WetSpass model needs to run the model. Therefore, Wells data was obtained from (Ministry of Water Resources, General Commission for groundwater, Wasit Branch). Figure 5 shows the groundwater level for the study area.

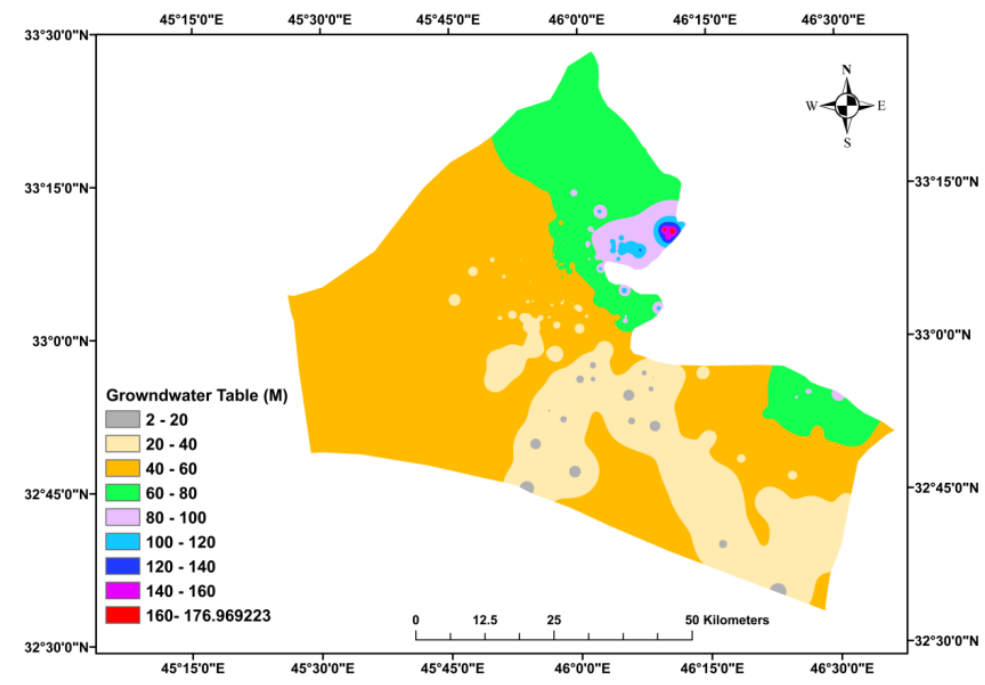

Figure 5 groundwater level for the study area

\subsubsection{Precipitation}

Figure $6(a, b)$ shows the two maps of precipitation for the winter and summer seasons over the study area from 2014 to 2019 , where the average rainfall ranges from $177.860 \mathrm{~mm}$ to $226.320 \mathrm{~mm}$ at an average of $217.508 \mathrm{~mm}$. and a standard deviation of $16.004 \mathrm{~mm}$ for the winter season and average rainfall ranges from $9 \mathrm{~mm}$ to 46.486 $\mathrm{mm}$ for the summer season. The essential aspect of the hydrological process is precipitation. It is the driving force in the hydrological cycle and the availability of water, which will eventually recharge the groundwater system. Precipitation is an important source of groundwater recharge, especially in dry and semi-arid environments [30]. 


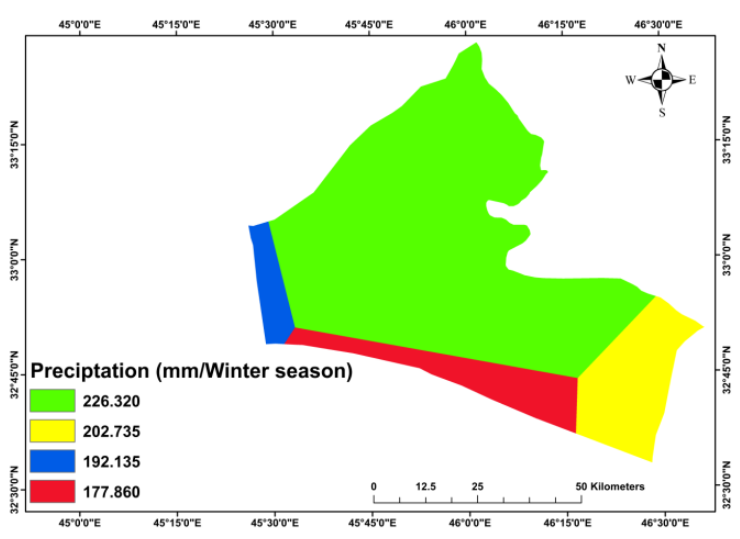

(a)

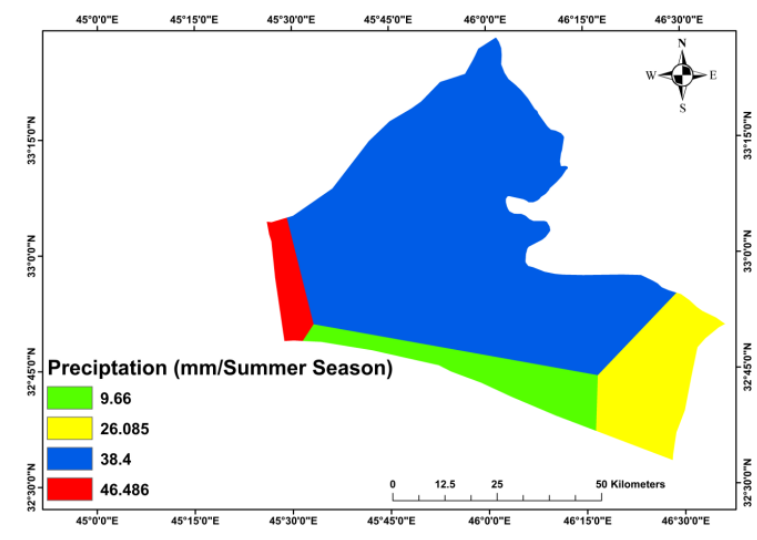

(b)

Figure 6 (a) Precipitation winter season, (b) Precipitation summer season

\subsubsection{Temperature}

Figure 7 (a) shows the two temperature maps during the winter and summer seasons. The average temperature during the winter season ranged from $16.35 \mathrm{C}^{\circ}$ to $18.29 \mathrm{C}^{\circ}$ at a rate of $17.034 \mathrm{C}^{\circ}$, while Figure 7 (b) shows the average temperature during the summer season ranged from $33.42 \mathrm{C}^{\circ}$ to $35.82 \mathrm{C}^{\circ}$ with a rate of $34.533 \mathrm{C}^{\circ}$ for the region of study during the period 2014-2019. Temperature affects groundwater recharge, as the relationship between temperature and recharge is inverse.

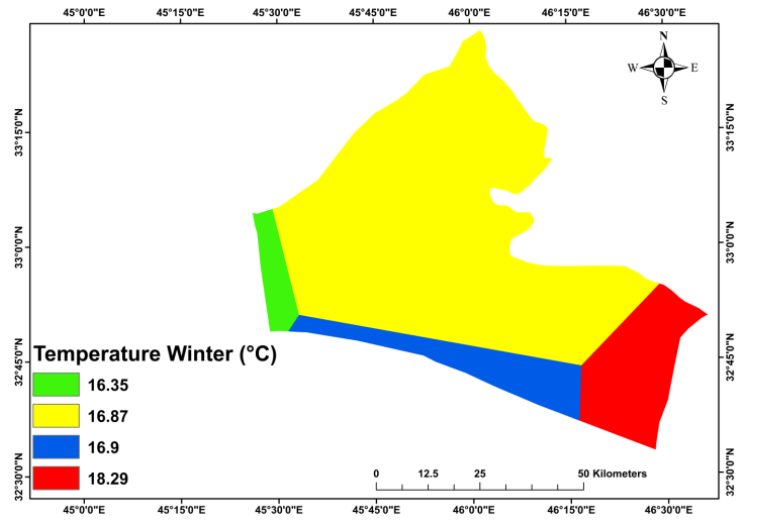

(a)

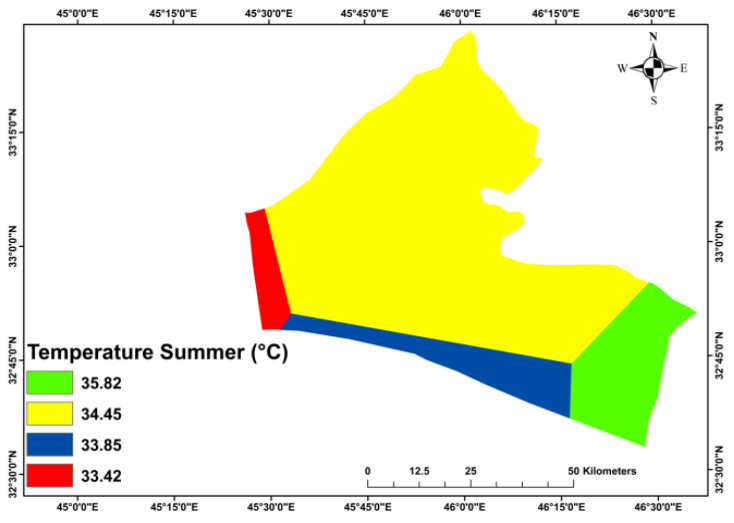

(b)

Figure 7 (a) Temperature for the winter, (b) Temperature for the summer

\subsubsection{Wind speed}

Figure 8 (a) shows the two maps of the average wind speed for the study area for the winter and summer seasons during the period 2014-2019. The average wind speed for the winter season ranged from $2.675 \mathrm{~m} / \mathrm{sec}$ to $3.123 \mathrm{~m} / \mathrm{sec}$ at an average rate of 2.749 , while the rate wind speed during the summer season ranged from 3.093 $\mathrm{m} / \mathrm{sec}$ to $4.143 \mathrm{~m} / \mathrm{sec}$ at a rate of $34.533 \mathrm{~m} / \mathrm{s}$. While Figure 8 (b) shows the rate wind speed during the summer season ranged from $3.093 \mathrm{~m} / \mathrm{sec}$ to $4.143 \mathrm{~m} / \mathrm{sec}$ at a rate of $34.533 \mathrm{~m} / \mathrm{s}$. 


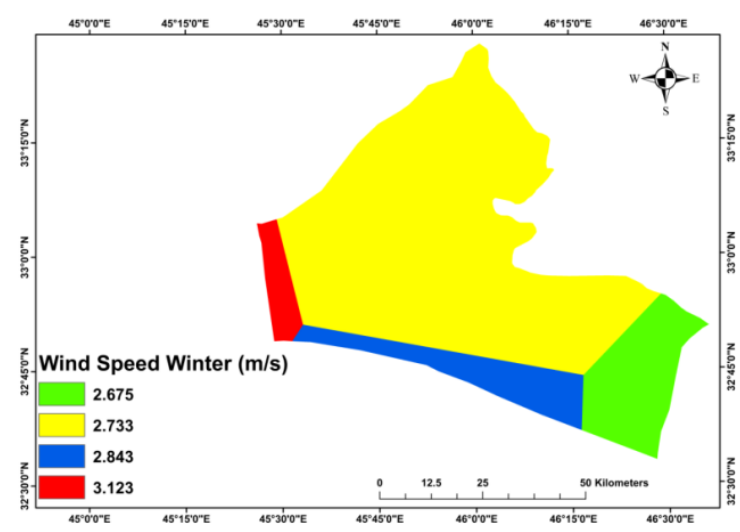

(a)

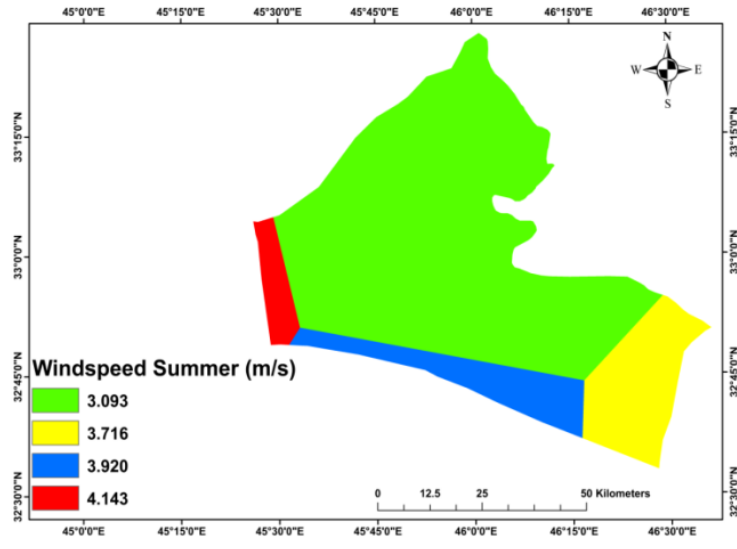

(b)

Figure 8 (a) the wind speed for the winter, (b) the wind speed for the summer

\subsubsection{Potential evapotranspiration}

The method (Thornthwaite 1984) was used to make accurate calculations of potential transpiration evaporation. This method is more suitable for the study area than other methods because it depends on the average monthly temperatures and the information available for modifying the radiation hours during the day. Figure $9(a, b)$ shows the potential evapotranspiration maps during the winter and summer seasons. The potential evapotranspiration rate ranges from $202.136 \mathrm{~mm}$ to $241.630 \mathrm{~mm}$ during the winter season rate of $215.346 \mathrm{~mm}$. At the same time, the evapotranspiration rate in the summer ranges from $1171.785 \mathrm{~mm}$ to $1209.588 \mathrm{~mm}$, at an average of $1191.122 \mathrm{~mm}$. Thus, the rate of potential evapotranspiration during the summer season is high due to high temperatures.

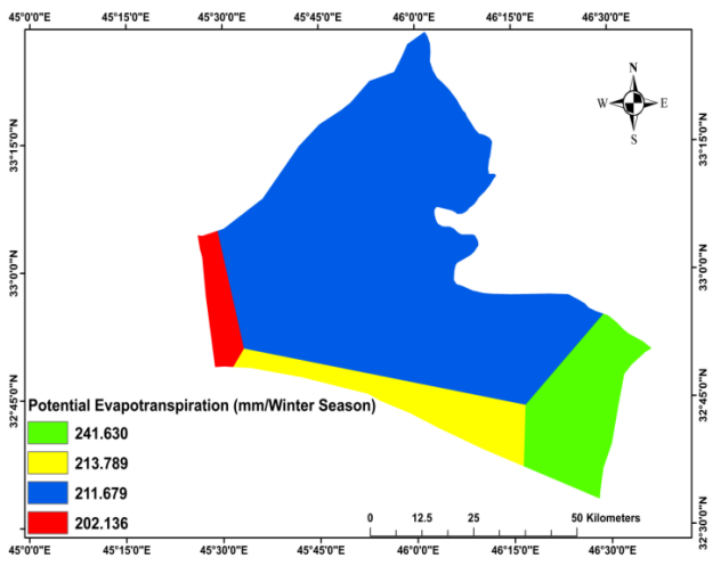

(a)

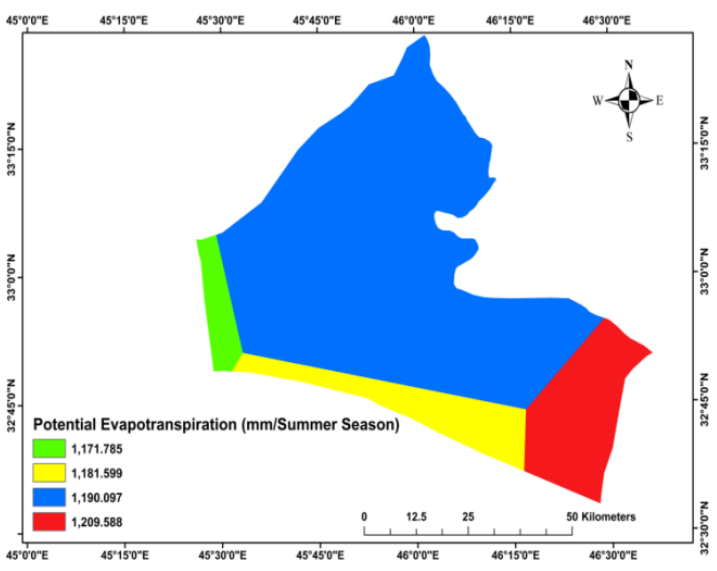

(b)

Figure 9 (a) Potential evapotranspiration for the winter season, (b) Potential evapotranspiration for the summer season

\section{RESULTS AND DISCUSSION}

Figure 10 shows the spatially distributed annual recharge values ranging from 0 to $65.176 \mathrm{~mm} / \mathrm{year}$ at a 27.117 $\mathrm{mm} / \mathrm{year}$ rate distributed over the study area of $5043 \mathrm{~km} 2$. The volume of water from the annual recharge obtained by groundwater is 136.751 million cubic meters of groundwater. 


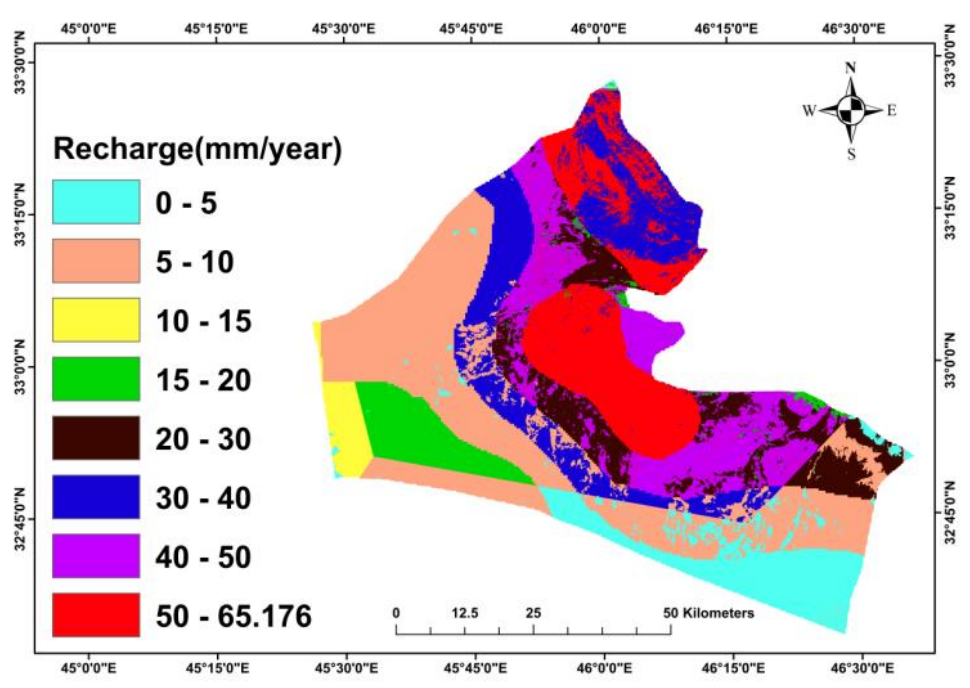

Figure 10 groundwater recharge map for the period (2014-2019)

Table 3 shows the distribution of annual recharge in the study area. The value of the recharge spatially distributed $(0-5) \mathrm{mm}$. This value represents $9.615 \%$ from the area of study. This part is located in southwestern part of the study area. The soil texture in this part is sandy clay loam. The land cover is agricultural land and bare land section. The topography of this part ranges from (10-30) $\mathrm{m}$ above sea level, and the groundwater level in this part is (20-60) $\mathrm{m}$. The value of the spatially distributed recharge is (10-5) $\mathrm{mm}$. This value represents $28.224 \%$ of the area of the study area, and this section of the research area is in the northwest corner. The soil texture in this part is sandy clay loam. The vegetation cover is barren land. The topography of this part ranges from (30-20) $\mathrm{m}$ from sea level, and the groundwater level in this part is (40-60) $\mathrm{m}$. The value of recharge (10-15) mm constitutes about $2.388 \%$ from the area of study and is located in the north western part. The soil texture in this part is silt loam, type of vegetation cover, bare land, groundwater level (40-60) m terrain (10 -20) $\mathrm{m}$ above sea level. Distributed recharge (15-20) $\mathrm{mm}$. This part constitutes 66.5 percent of the area of the study area. This part is located northwest of the study area. Soil type silt loam, land cover, bare land. Groundwater level (40-60) $\mathrm{m}$ and topography (10 -30) $\mathrm{m}$. Distributed feeding (20-30) $\mathrm{mm}$. This part constitutes $94.95 \%$ of the area. This part is located in the middle of the study area, soil texture Sand Loamy. The vegetation cover in this part is barren land and agricultural lands. The topography of this part is (30-70) $\mathrm{m}$ level. The groundwater level in this part (20-60m). Distributed recharge (30-40) $\mathrm{mm}$. This part constitutes $4.114 \%$ of the area. This part is located in the middle and north of the study area. Soil type is Sandy Loam, land cover, and part of agricultural cropland. Distributed recharge (40-50) $\mathrm{mm}$ This part constitutes $13.03 \%$ of the area. This part is located in the middle of the study area. Soil type loamy sand land cover Agricultural croplands and barren lands groundwater level (20-60) m topography (40-70) $\mathrm{m}$. The spatially distributed nutrition (50-65.176) $\mathrm{mm}$. This part is located in the middle of the study area and constitutes $17.021 \%$ of the area of the study area. Soil type: Sandy soil, land cover, agricultural croplands and bare lands. Figure 11 shows the study area's spatially distributed annual surface runoff map (2014-2019). The annual runoff ranges of ( 0 to 113.752$) \mathrm{mm}$, with an average of $13.07 \mathrm{~mm}$ and a standard deviation of 17.989 .

Table 3 Annual recharge spatial distribution for the period (2014-2019)

\begin{tabular}{|c|c|c|c|}
\hline No. & Recharge( $\mathbf{m m} /$ year $)$ & Area $\left(\mathbf{K m}^{\mathbf{2}}\right)$ & Percent from study area \% \\
\hline 1 & $0-5$ & 484.899 & 9.615 \\
\hline 2 & $5-10$ & 1423.361 & 28.224 \\
\hline 3 & $10-15$ & 120.449 & 2.388 \\
\hline 4 & $15-20$ & 285.543 & 5.662 \\
\hline 5 & $20-30$ & 501.528 & 9.945 \\
\hline 6 & $30-40$ & 711.752 & 14.114 \\
\hline 7 & $40-50$ & 657.095 & 13.030 \\
\hline 8 & $50-65.176$ & 858.373 & 17.021 \\
\hline
\end{tabular}




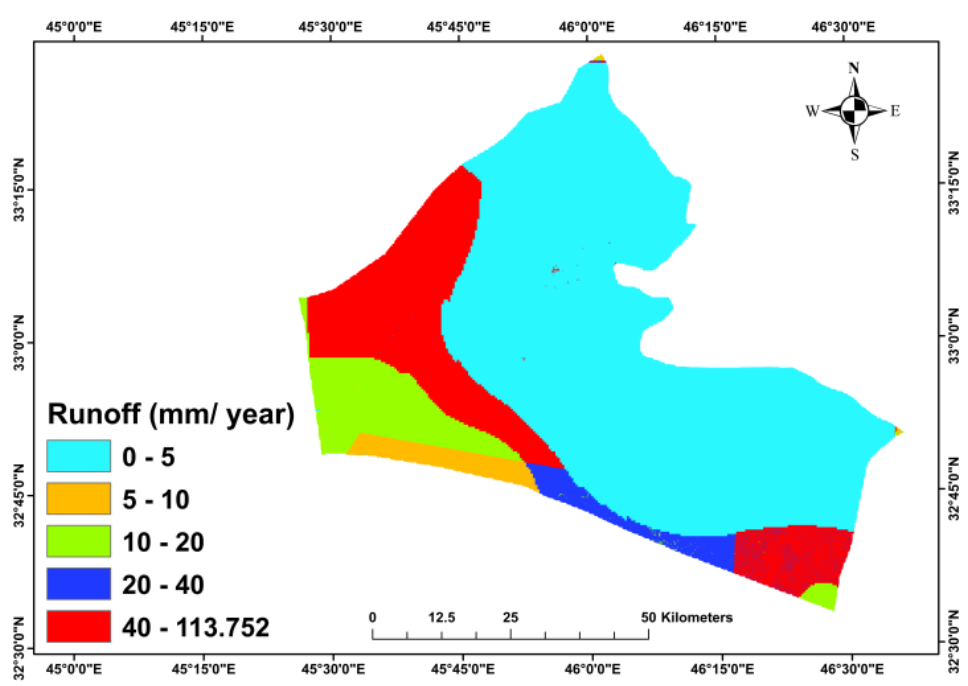

Figure 11 Runoff for the period (2014-2019)

Table 4 shows the annual runoff values distributed spatially over the area of the study area for the period (2014-2019). The value (0-5) mm occupies the largest area of the study area, representing $66.543 \%$. Figure 12 shows the map of the actual annual evapotranspiration in the study area (2014-2019), values ranging from $131.725 \mathrm{~mm}$ to $1373.921 \mathrm{~mm}$ at a rate of $209.316 \mathrm{~mm}$.

Table 3 Annual Runoff spatial distribution for the period (2014-2019)

\begin{tabular}{|c|c|c|c|}
\hline No. & Annual runoff $(\mathbf{m m} /$ year $)$ & Area $\left(\mathbf{K m}^{\mathbf{2}}\right)$ & Percent from study area \% \\
\hline 1 & $0-5$ & 3355.747 & 66.543 \\
\hline 2 & $5-10$ & 131.229 & 2.602 \\
\hline 3 & $10-20$ & 404.839 & 8.028 \\
\hline 4 & $20-40$ & 162.260 & 3.218 \\
\hline 5 & $40-113.752$ & 988.924 & 19.610 \\
\hline
\end{tabular}

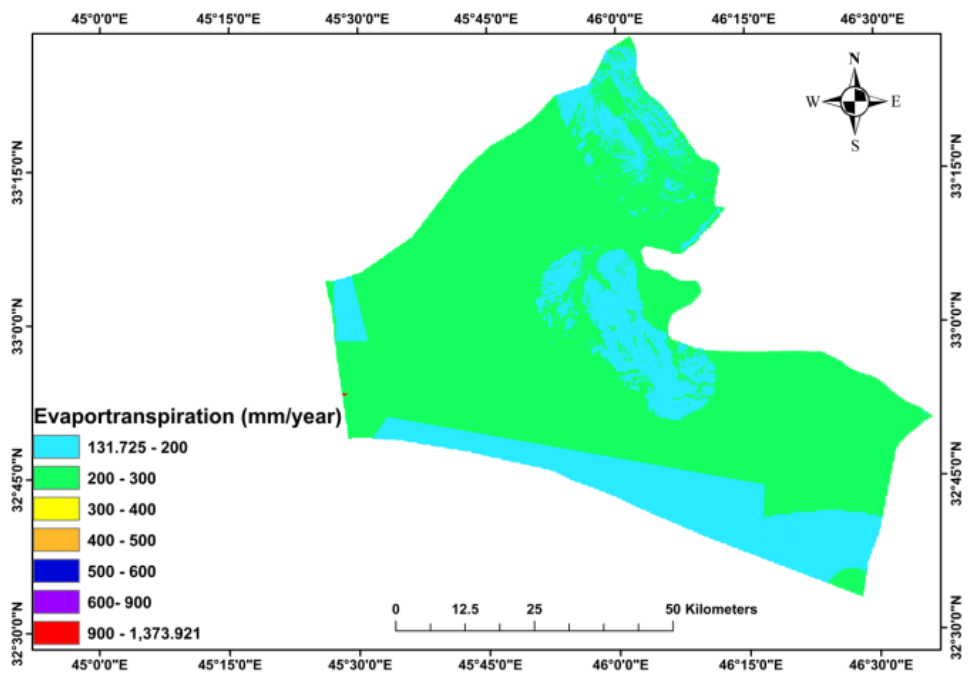

Figure 12 Evapotranspiration for the period (2014-2019) 
Table 5 shows the annual evapotranspiration values distributed spatially over the area of the study area for the period (2014-019). The value (200-300) covers the most significant proportion of the area of the study area, which constitutes $74.288 \%$.

Table 5 Annual Evapotranspiration spatial distribution for the period (2014-2019)

\begin{tabular}{|c|c|c|c|}
\hline No. & Evapotranspiration $(\mathbf{m m} /$ year $)$ & Area $\left.\mathbf{( K m}^{\mathbf{2}}\right)$ & Percent from study area\% \\
\hline 1 & $131.725-200$ & 1296.306 & 25.70505 \\
\hline 2 & $200-300$ & 3746.361 & 74.28834 \\
\hline 3 & $300-400$ & 0.333604 & 0.006615 \\
\hline
\end{tabular}

\section{CONCLUSIONS}

In this study, the WetSpass model was applied to calculate the spatially distributed annual recharge for the eastern part of Wasit province, Iraq. The WetSpass model displayed that the average annual recharge in the study area was $27.117 \mathrm{~mm} /$ year, about $10.8 \%$ of the annual rainfall rate (136.75 million meter cubics). High recharge occurred in Agricultural lands and the sandy texture soil class. As a result of sandy soils' high permeability and the absence of surface runoff on agricultural regions with relatively mild slopes, low recharge was observed in areas with barren lands that contain clay soils and wet drainage areas. Evaporation formed about $83.33 \%$ of the yearly average precipitation in the study area. The results indicated that evapotranspiration is the main process of water loss in the study area due to high temperatures, solar radiation, and the persistence of strong dry winds. Assess groundwater recharge in east Wasit province, critical for integrated groundwater modelling and effective long-term planning and management of the region's available water resources. The geographic variability of groundwater recharge is influenced by climate data, groundwater depth, distributed land cover, soil texture, terrain, and slope. Soil textures and land cover. The spatially distributed Wetspass model was used to calculate the long-range annual and seasonal recharge of groundwater and the water balance components for the eastern region of Wasit Province.

\section{ACKNOWLEDGEMENTS}

The authors provide their sincere thanks and gratitude to Wasit University - College of Engineering, and the General Authority for Ground Water, Wasit Branch, for providing the wells data requested by the paper and support.

\section{REFERENCES}

1. Aeschbach-Hertig, W., \& Gleeson, T. (2012). Regional strategies for the accelerating global problem of groundwater depletion. Nature Geoscience, 5(12), 853-861.

2. Freeze, R. A., \& Cherry, J. A. (1979). Groundwater. New Jersey: Prentice-Hall geochemical parameter distribution in a groundwater system contaminated with petroleum hydrocarbons. Journal of Environmental Quality, 30, 1548-1563.

3. Morris, B. L., Lawrence, A. R., Chilton, P. J. C., Adams, B., Calow, R. C., \& Klinck, B. A. (2003). Groundwater and its susceptibility to degradation: a global assessment of the problem and options for management.

4. Shukla, S., \& Jaber, F. H. (2006). Groundwater recharge from agricultural areas in the Flatwoods Region of South Florida. EDIS, 2006(15).

5. Batelaan, O., \& De Smedt, F. (2007). GIS-based recharge estimation by coupling surface-subsurface water balances. Journal of hydrology, 337(3-4), 337-355.

6. Batelaan, O., \& De Smedt, F. L. O. R. I. M. O. N. D. (2001). WetSpass: a flexible, GIS-based, distributed recharge methodology for regional groundwater modelling. IAHS PUBLICATION, 11-18.

7. El Idrysy, Houcyne, and Florimond De Smedt. "Modelling groundwater flow of the Trifa aquifer, Morocco." Hydrogeology Journal 14, no. 7 (2006): 1265-1276.

8. Abu-Saleem, A., Al-Zu'bi, Y., Rimawi, O., Al-Zu'bi, J., \& Alouran, N. (2010). Estimation of water balance components in the Hasa basin with GIS-based WetSpass model. Journal of Agronomy, 9(3), 119-125. 
9. Park, C., Seo, J., Lee, J., Ha, K., \& Koo, M. H. (2014). A distributed water balance approach to groundwater recharge estimation for Jeju volcanic island, Korea. Geosciences Journal, 18(2), 193-207.

10. Ghouili, Nesrine, Faten Jarraya Horriche, Mounira Zammouri, Sihem Benabdallah, and Boutheina Farhat. "Coupling WetSpass and MODFLOW for groundwater recharge assessment: a case study of the Takelsa multilayer aquifer, northeastern Tunisia." Geosciences Journal 21, no. 5 (2017): 791-805.

11. Al Kuisi, M., \& El-Naqa, A. (2013). GIS-based spatial groundwater recharge estimation in the Jafr basin, Jordan-application of WetSpass models for arid regions. Revista Mexicana de Ciencias Geológicas, 30(1), 96-109.

12. Teklebirhan, A., Dessie, N., \& Tesfamichael, G. (2012). Groundwater recharge, evapotranspiration and surface runoff estimation using WetSpass modelling method in Illala Catchment, Northern Ethiopia. Momona Ethiopian Journal of Science, 4(2), 96110.

13. El Garouani, A., Aharik, K., \& El Garouani, S. (2020). Water balance assessment using remote sensing, Wet-Spass model, CN-SCS, and GIS for water resources management in Saïss Plain (Morocco). Arabian Journal of Geosciences, 13(15), 1-9.

14. Salem, A., Dezső, J., \& El-Rawy, M. (2019). Assessment of groundwater recharge, evaporation, and runoff in the Drava Basin in Hungary with the WetSpass Model. Hydrology, 6(1), 23.

15. Nannawo, A. S., Lohani, T. K., \& Eshete, A. A. (2021). Exemplifying the Effects Using WetSpass Model Depicting the Landscape Modifications on Long-Term Surface and Subsurface Hydrological Water Balance in Bilate Basin, Ethiopia. Advances in Civil Engineering, 2021.

16. Ashaolu, E. D., Olorunfemi, J. F., Ifabiyi, I. P., Abdollahi, K., \& Batelaan, O. (2020). Spatial and temporal recharge estimation of the basement complex in Nigeria, West Africa. Journal of Hydrology: Regional Studies, 27, 100658.

17. Kahsay, G. H., Gebreyohannes, T., Gebremedhin, M. A., Gebrekirstos, A., Birhane, E., Gebrewahid, H., \& Welegebriel, L. (2019). Spatial groundwater recharge estimation in Raya basin, Northern Ethiopia: an approach using GIS-based water balance model. Sustainable Water Resources Management, 5(2), 961-975.

18. Meresa, E., \& Taye, G. (2019). Estimation of groundwater recharge using GIS-based WetSpass model for Birki watershed, the eastern zone of Tigray, Northern Ethiopia. Sustainable Water Resources Management, 5(4), 1555-1566.

19. Ghimire, U., Shrestha, S., Neupane, S., Mohanasundaram, S., \& Lorphensri, O. (2021). Climate and land-use change impacts on spatiotemporal variations in groundwater recharge: A case study of the Bangkok Area, Thailand. Science of The Total Environment, 148370.

20. Zeabraha, A., Mulugeta, A., \& Gebreyesus, Z. (2020). Application of a spatially distributed water balance model for assessing surface and groundwater resources: a case study of Adigrat area, Northern Ethiopia. Sustainable Water Resources Management, 6(4), 1-19.

21. Hassan, W. H. (2020). Climate change impact on groundwater recharge of Umm er Radhuma unconfined aquifer Western Desert, Iraq. International Journal of Hydrology Science and Technology, 10(4), 392-412.

22. Shamkhi, M. S., Mohson, A. J., \& Abdullah, T. J. (2019, August). Morphometric Analysis of Galal Bedrah River Basin Using STRM (DEM) Data and GIS Techniques. In AWAM International Conference on Civil Engineering (pp. 265-276). Springer, Cham. 
23. Manhi, H. K., \& Al-Kubaisi, Q. Y. S. (2021). Estimation Annual Runoff of Galal Badra Transboundary Watershed Using Arc Swat Model, Wasit, East of Iraq. The Iraqi Geological Journal, 69-81.

24. Sahar, A. A., Hassan, M. A., \& Abd Jasim, A. (2021). Estimating the Volume of Sediments and Assessing the Water Balance of the Badra Basin, Eastern Iraq, Using Swat Model and Remote Sensing Data. The Iraqi Geological Journal, 88-99.

25. Shamkhi, M. S., \& Al-Badry, H. J. (2021). Assessment of Groundwater Recharge Potential Depending on Morphologic Analysis in East of Wasit, Southeastern Iraq. The Iraqi Geological Journal, 138-154.

26. Aish, A. M., Batelaan, O., \& De Smedt, F. (2010). Distributed recharge estimation for groundwater modelling using WetSpass model, case study-Gaza strip, Palestine. Arabian Journal for Science and Engineering, 35(1), 155.

27. Graf, R., \& Kajewski, I. (2013). Forming of the water balance elements in the Mogilnica catchment on the basis of simulating investigations. Nauka Przyroda Technologie, 7(1).

28. Batelaan, O., De Smedt, F., \& Triest, L. (2003). Regional groundwater discharge: phreatophyte mapping, groundwater modelling and impact analysis of land-use change. Journal of hydrology, 275(1-2), 86-108.

29. Graf, R., \& Przybyłek, J. (2014). Estimation of shallow groundwater recharge using a GIS-based distributed water balance model.

30. Fetter, C. W. (2018). Applied hydrogeology. Waveland Press.

31. Tilahun, K., \& Merkel, B. J. (2009). Estimation of groundwater recharge using a GISbased distributed water balance model in Dire Dawa, Ethiopia. Hydrogeology Journal, 17(6), 1443-1457.

32. Cook, P. G., Walker, G. R., Buselli, G., Potts, I., \& Dodds, A. R. (1992). The application of electromagnetic techniques to groundwater recharge investigations. Journal of hydrology, 130(1-4), 201-229. 